\title{
O INSTANTE LÍQUIDO: \\ A FOTOGRAFIA E O PROCESSO DE IMERSÃO NA VIDA NAS ÁGUAS
}

\author{
Lanna Beatriz Lima Peixoto ${ }^{1}$
}

Este ensaio fotográfico teve origem na feitura da dissertação de mestrado intitulada "Cidade nas águas - um estudo sobre imaginário em Salvaterra-PA". Salvaterra é um município localizado no Arquipélago do Marajó, Estado do Pará, envolvido em águas, teve sua vida cultural, econômica, política estruturada em torno do diálogo entre humanos e os rios. Relação que constituiu um universo aquático rico em imagens, narrativas, saberes e fazeres sobre o lugar habitado, lugar esse aqui entendido a partir da extensão da experiência de moradores da terra para as águas. A dissertação se centrava no processo de formação das imagens e narrativas geradas nos rios da região, considerando seus entrelaçamentos, e o processo criativo que dá sentido a existência afetuosa no tempo e no espaço.

Em minha primeira viagem a Salvaterra - quando ainda nem vislumbrava o caminho que seguiria nessa pesquisa - decidi abrir mão de qualquer recurso, sem as amarras de blocos de notas, câmeras fotográficas ou gravadores. Dessa viagem só sobraram os registros que fiz quando cheguei a Belém, dessa viagem ficaram imagens gravadas em minha memória. O ambiente me pareceu tão milimetricamente encantado como se fizesse tudo parte de uma pintura, com cada traço pensado, mas uma imagem em especial foi como o primeiro impulso do que viria a desenvolver tempos mais tarde.

Era uma menina de aproximadamente 8 anos, morena, cabelos lisos, olhos curiosos. Conversamos em frente à casa em que ela morava na $1^{\mathrm{a}}$ Travessa, ela estava sentada sobre um mirante de madeira e me falava, apontando o lugar no rio, sobre um boto que vira certa vez. Quando a olhei por um instante percebi que seu rosto tinha como fundo a água, naquela ocasião azulada, e seus cabelos esvoaçavam como sobre a terra. Percebi a menina como a imanência dos dois elementos, e ela própria emanava sua existência sobre eles. Outras imagens naquela viagem ficaram na memória, mas essa, por sua composição, pelos elementos contidos ali em frente aos meus olhos,

\footnotetext{
${ }^{1}$ Universidade Federal do Pará, Brasil.

${ }^{2}$ Dissertação apresentada ao Programa de Pós-graduação em Linguagens e Saberes na Amazônia da Universidade Federal do Pará.
} 
naquele enquadramento que me falava tanto, por ele mesmo, sem que necessitasse de nenhum esforço interpretativo ressoou em mim de uma forma mais inquietante. Porém em momento algum lamentei que não tivesse a câmera fotográfica em mãos, ficou o momento.

Foram desses momentos não fotografáveis que nasceu interesse pela fotografia. Há momentos que devem ser respeitados e guardados somente no segredo da memória, em seu trabalho silencioso. Anos depois daquela primeira viagem a campo, ainda não consigo, e creio não ser possível, definir em palavras como cada instante deve ser apreendido e, ainda mais, com que formas eternizá-lo. Creio que a resposta quem dará será sempre o instante.

A compreensão do instante pressupõe uma sensibilidade empregada na experiência, viver o momento em sua intensidade. Portanto, primeiro me detive a abrir as portas e sensibilizar as formas de olhar e daí cheguei ao estudo do imaginário. $\mathrm{O}$ imaginário diz respeito ao aspecto sensível da vida social, é constituído por ele, portanto só uma abordagem metodológica sensível nos leva até ele. Foi essa abordagem que me levou também à fotografia. Esse interesse foi evoluindo junto com o trabalho a ponto de se tornar parte integrante e indivisa, essencial a pensar como as imagens repercutem em nós, atestando como as coisas repercutem em nós, que falam e nos induzem a pensar (Barthes, 2012: 41).

Foi através da fotografia que pude vislumbrar a materialização da afirmação de Maffesoli (2001): o “imaginário é uma realidade”. Para ele o imaginário enquanto comunhão é sempre comunicação, a fotografia materializa a forma como a coisa, "necessariamente real, sem a qual não haveria a fotografia" (Barthes, 2012: 72), a imagem dela propriamente dita, repercute em seu produtor e ainda ressoa no espectador. Essa repercussão é resultado de um amálgama da experiência individual e das referências sociais em que está imerso o sujeito que olha. A fotografia enquanto técnica alimenta e é alimentada pelo imaginário, "a técnica é um fator de estimulação imaginal" (Maffesoli, 2001: 80). Com técnica Roland Barthes (Barthes, 2012: 75) nos estimula a pensar a fotografia:

A partir do dia em que uma circunstancia científica (a descoberta da sensibilidade dos sais de prata à luz) permitiu captar e imprimir diretamente os raios luminosos emitidos por um objeto diversamente iluminado. A foto é literalmente uma emanação do referente. De um corpo real, que estava lá, partiram radiações que vêm me atingir, a mim, que estou aqui; pouco importa a duração da transmissão; a foto do ser desaparecido vem me tocar como os raios retardados de uma estrela. Uma 
espécie de vínculo umbilical liga a meu olhar o corpo da coisa fotografada: a luz, embora impalpável, é aqui um meio carnal, uma pele que partilho com aquele ou aquela que foi fotografado.

Enriqueço ainda a discussão com uma observação de Barthes sobre o simbolismo deste processo: "o corpo é imortalizado pela mediação de um metal precioso, a prata (monumento e luxo); ao que acrescento a ideia de que esse metal, como todos os metais da Alquimia, está vivo", e acrescentaria ainda mais por conta própria: por que vaza e escorre em mim. É por isso que as imagens construídas nesse encontro não serão provas da veracidade do "eu estive lá", mas do "eu estou aqui", "imagens especulares da vida cotidiana” (Rocha, 2003: 120), estou aqui impressa também de corpo inteiro nas páginas que sustentam palavras e imagens. Assim assimilo toda a reflexão sobre a construção ética e estética que funda a própria narrativa antropológica que surge com a antropologia visual (Rocha, 1995: 113).

O que implica no entendimento da fotografia mais como porta, no sentido simmeliano do termo, "que cria por assim dizer, uma junção entre o espaço da pessoa e tudo que se encontra fora dele, abole a separação entre interior e exterior" (Simmel, 1996: 03). Para Simmel, a porta é um comunicador de mão dupla, onde se entra e sai, ao contrário da janela, que remete a uma relação meramente visual, de onde se olha para fora, do interior para o exterior (Simmel, 1996: 04), o ser que olha é apenas receptor do mundo. Nesse sentido, é fundamental a noção de jogo à que recorre Vilém Flusser (2002: 75), para este autor só através dele é possível exercer nossa liberdade frente ao aparelho fotográfico, afim de que seu operador não se torne um refém. Estendendo-a percebo que no que se refere à antropologia é fundamental o jogar no processo fotográfico em todos os níveis: na introdução do aparelho em campo; em seu manuseio técnico; e por fim na tessitura da narrativa etnográfica.

Os materiais audiovisuais são olhares sobre o mundo, levados pela intencionalidade de uma pessoa, que destina sua mensagem visível a outro olhar, procurando dar significação a este mundo (Samain apud Achutti, 1997: 36). A porta fala e há quem a escute, quem a interprete, quem a recrie. De acordo com Mead e Bateson “os materiais visuais, antes de serem cópias da realidade, são 'textos', afirmações e interpretações" (Mead; Bateson apud Achutti, 1997: 25). É como instrumento de experimentação e interpretação da relação dialógica entre a palavra e a imagem, que insiro as linguagens audiovisuais em meu trabalho, abrindo mão do esforço inútil de 
tentar domesticar a poésis que as sustenta. Entendendo-as como importantes instrumentos de exploração e interpretação de dinâmicas sociais.

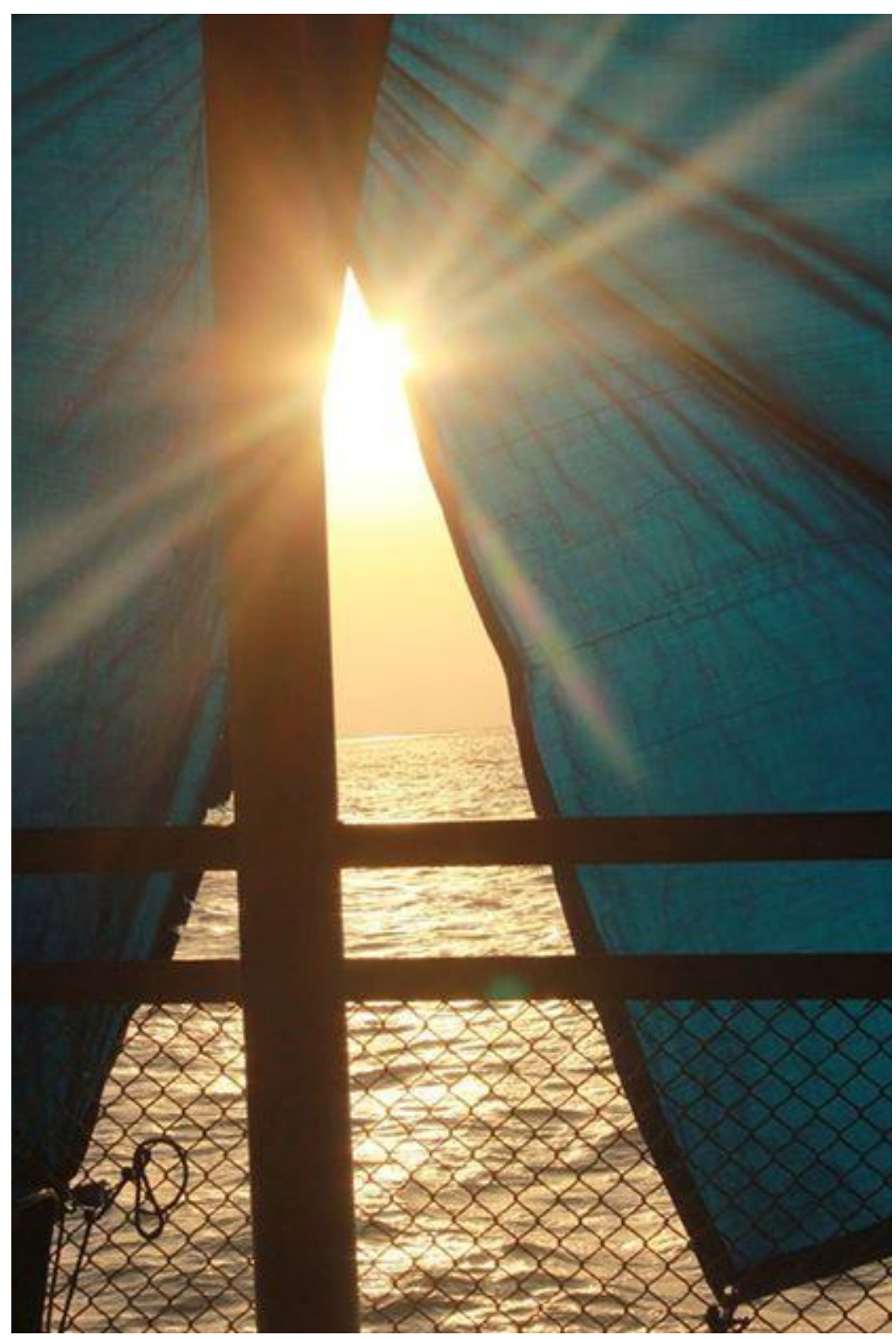



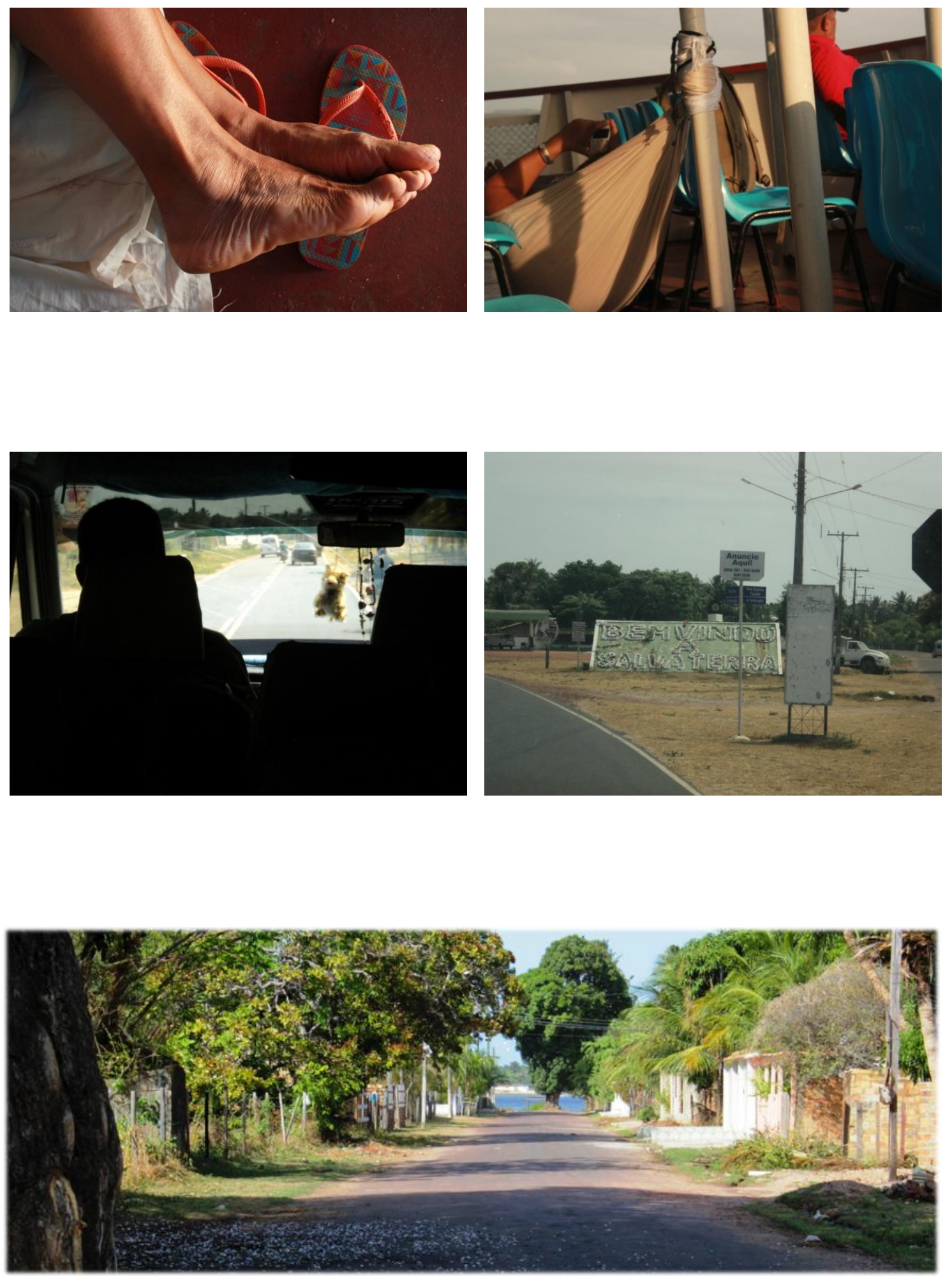

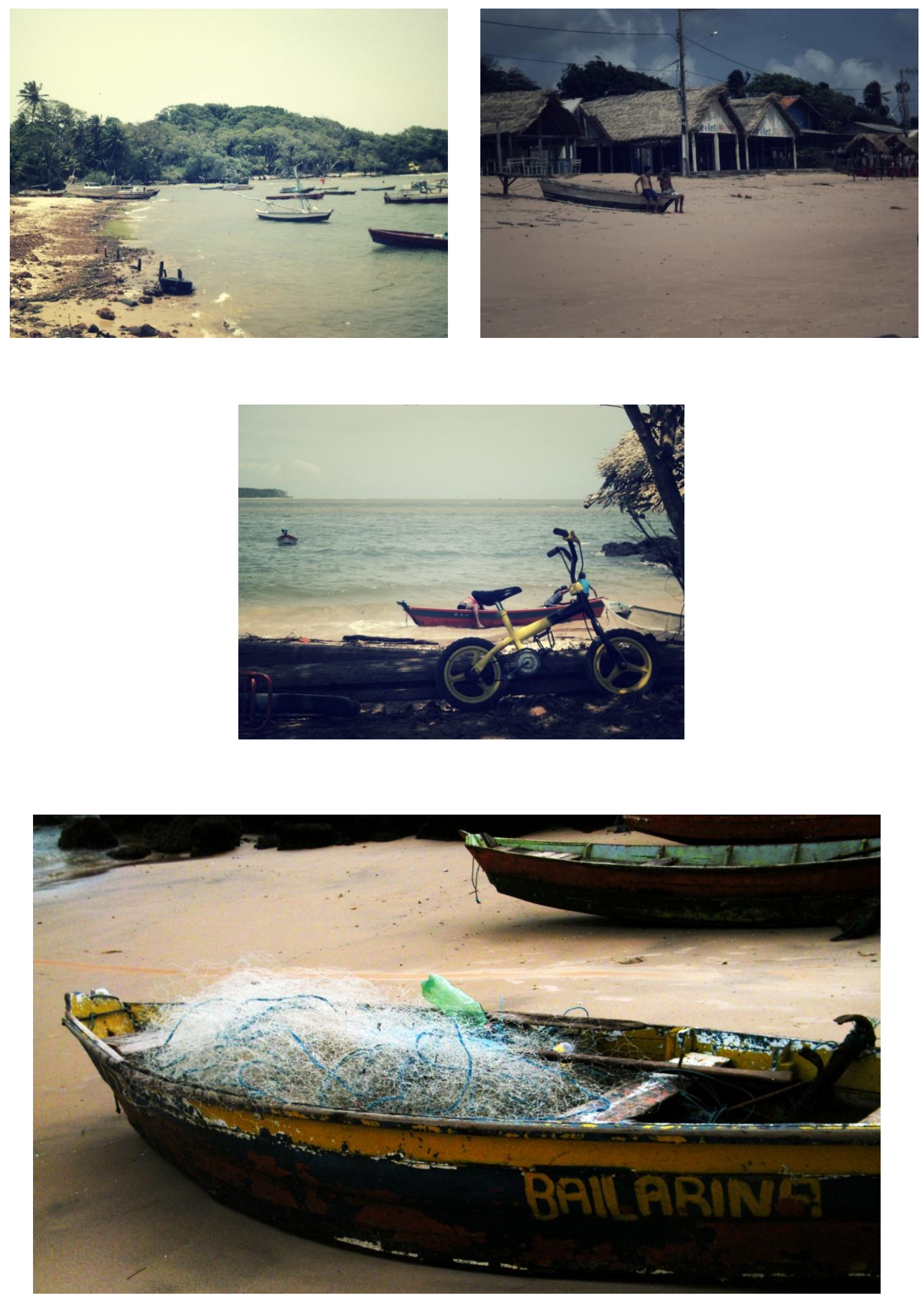

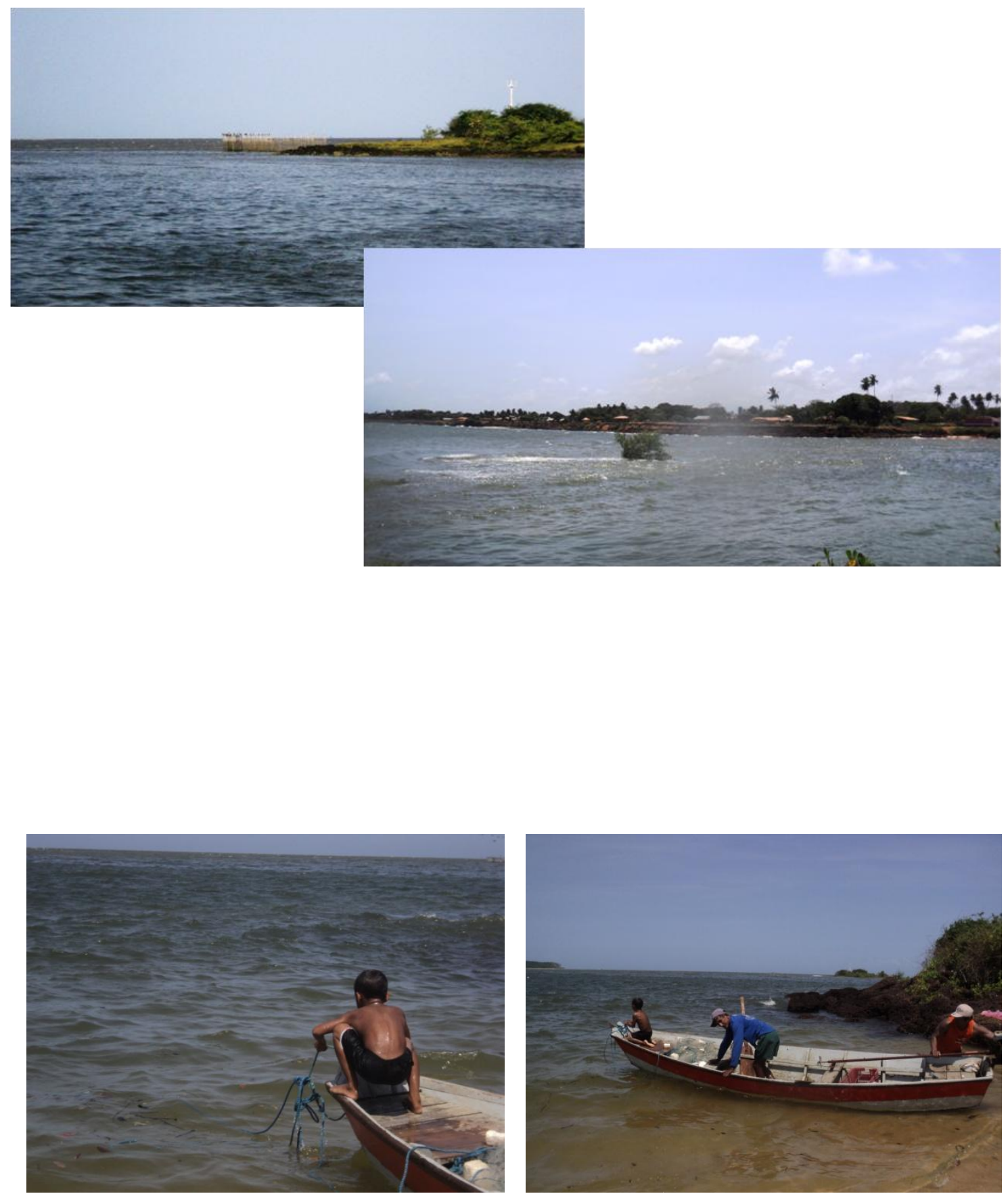

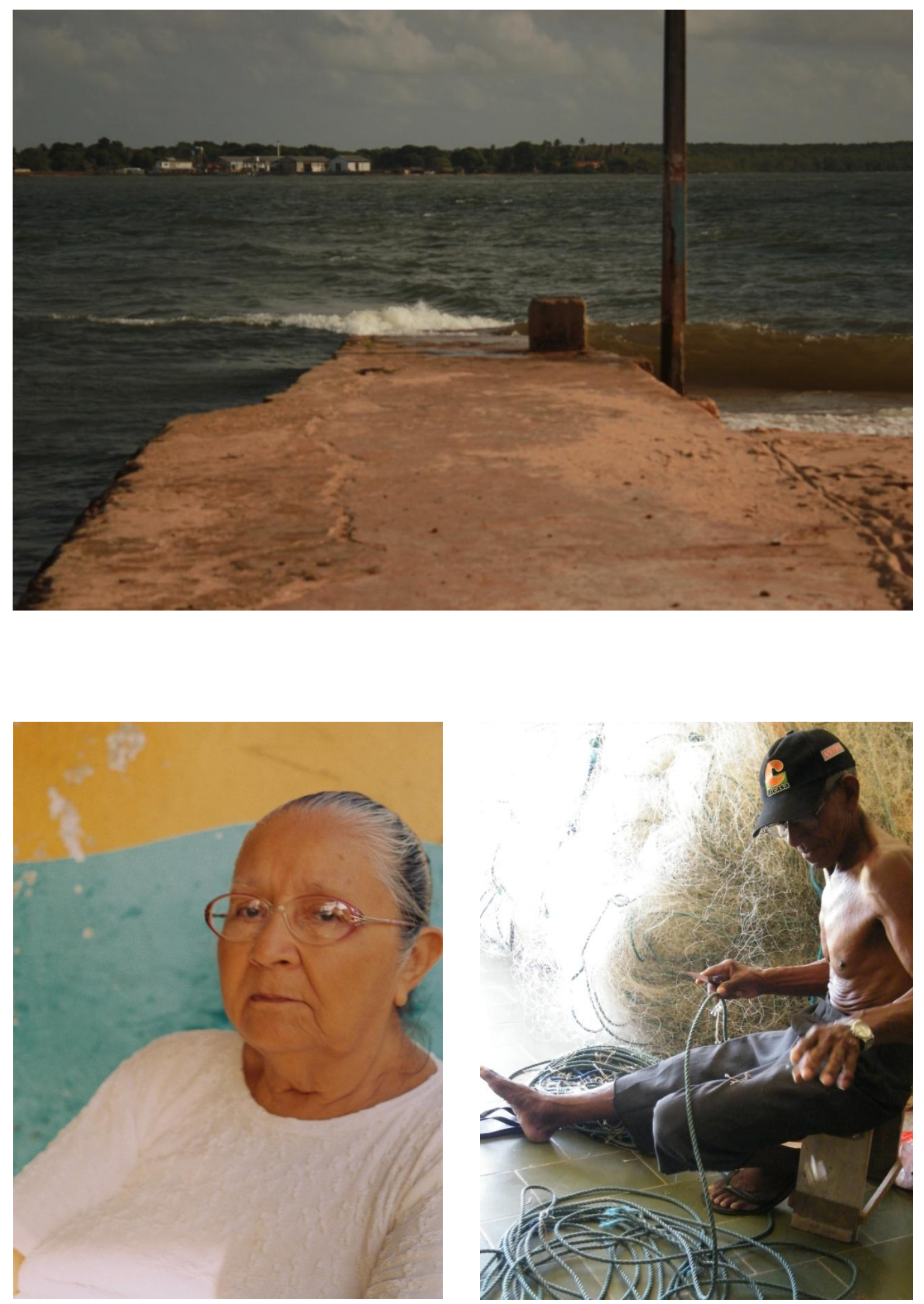

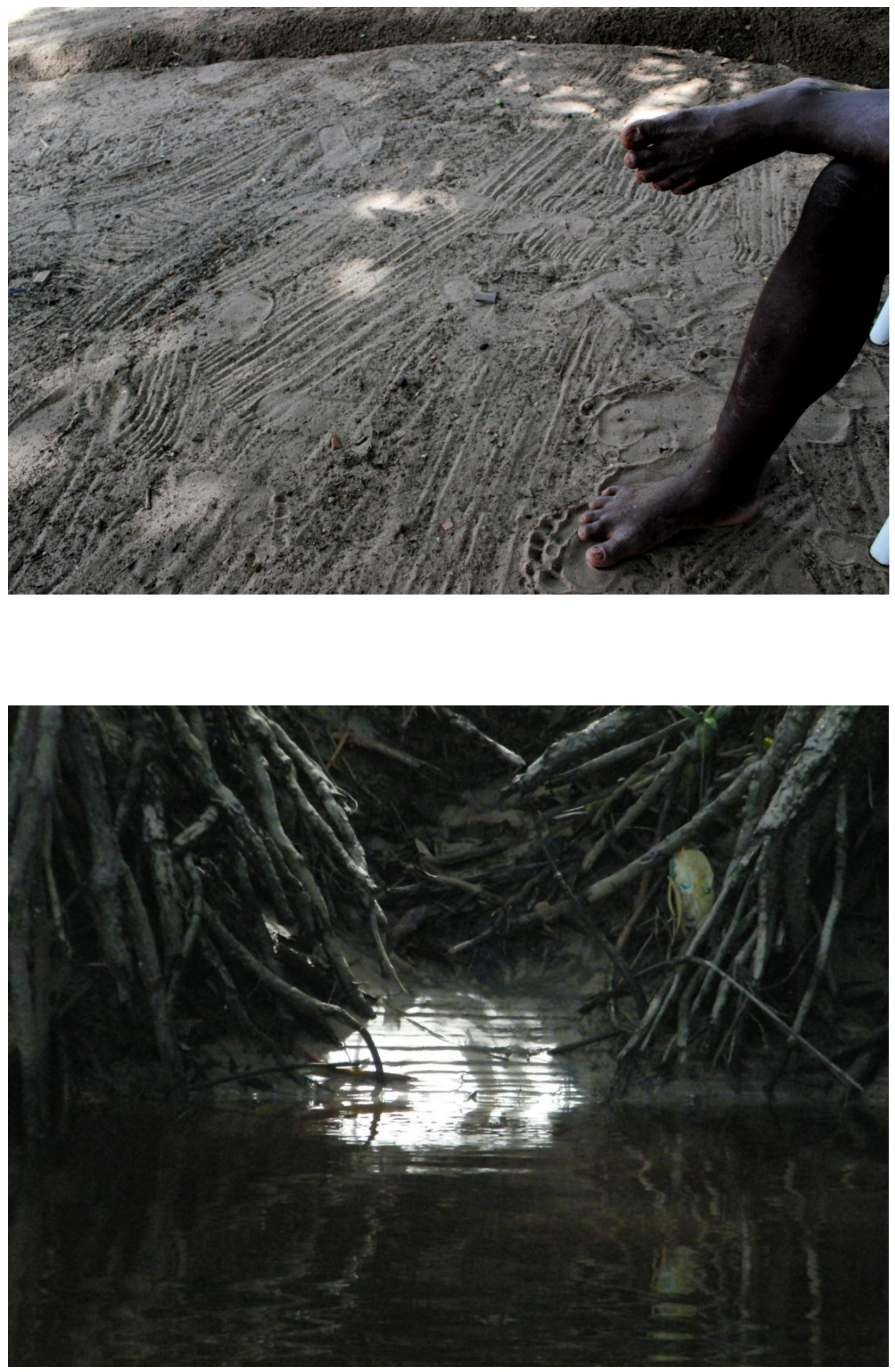

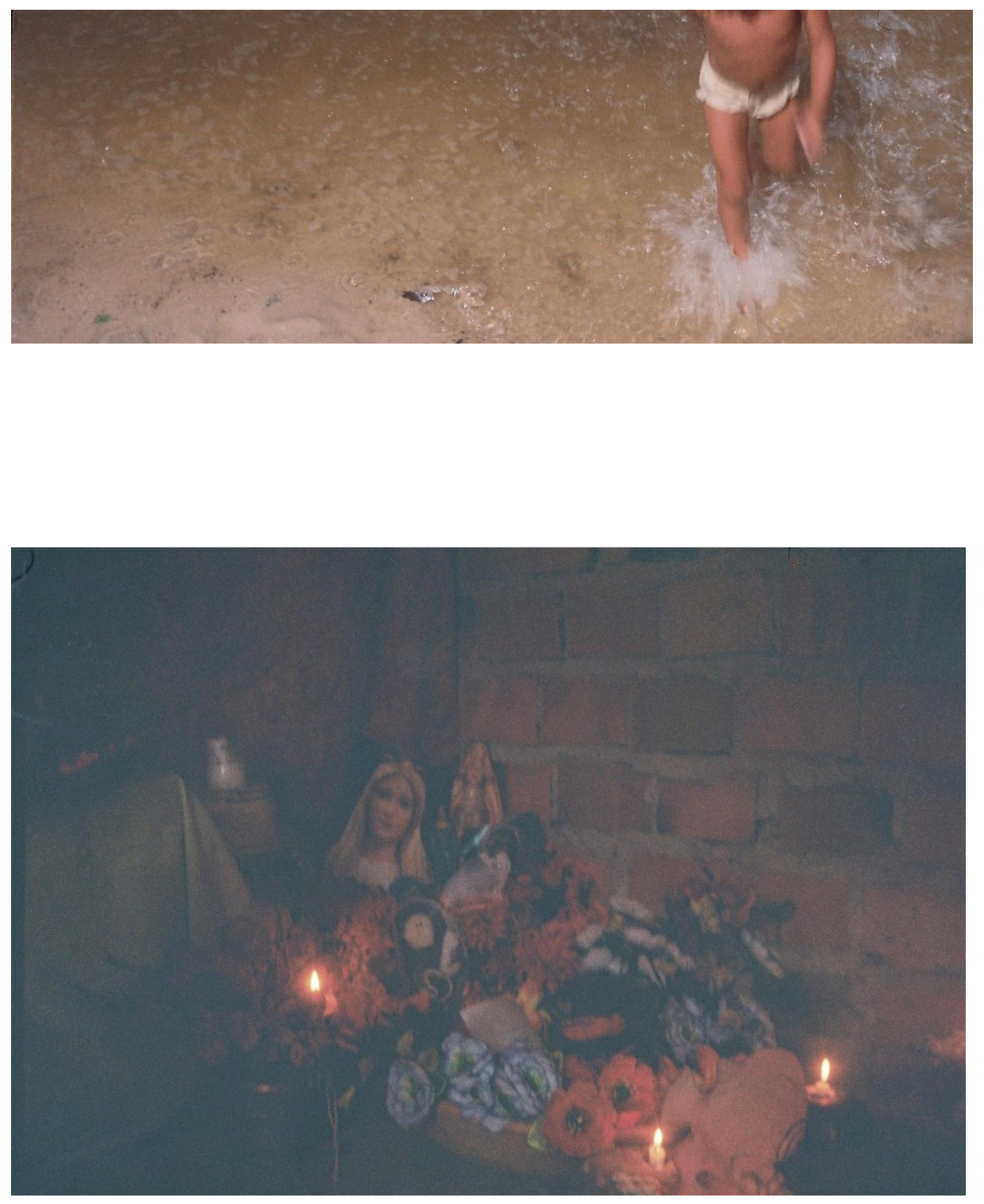

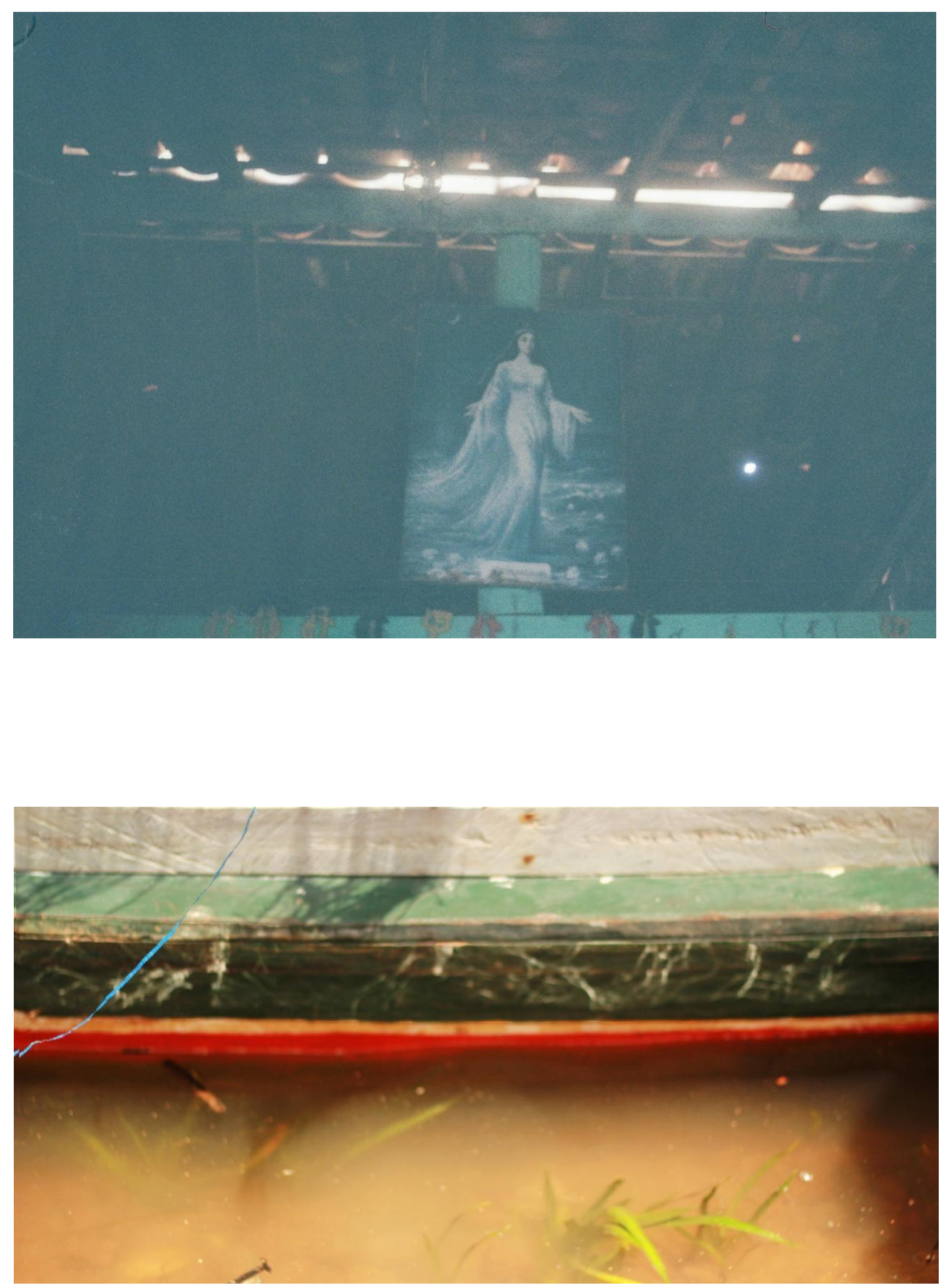

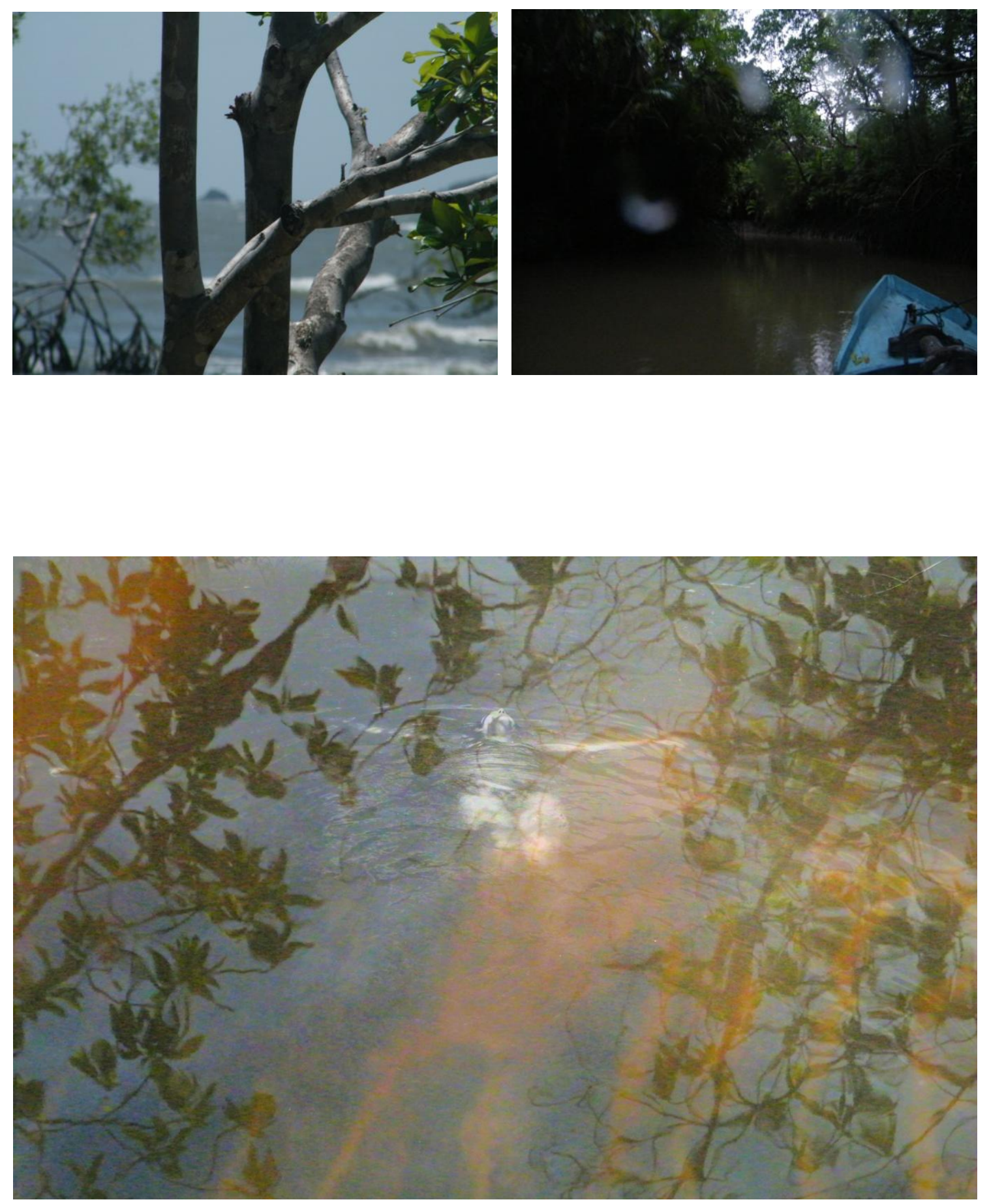


\section{Referências}

ACHUTTI, Luis Eduardo R.. Fotoetnografia. Um estudo de antropologia visual sobre cotidiano, lixo e trabalho. Porto Alegre: Tomo Editorial; Palmarinca, 1997.

BARTHES, Roland. A câmara clara: nota sobre a fotografia. Rio de Janeiro: Nova Fronteira, 2012.

FLUSSER, Vilém. Filosofia da caixa preta. Ensaios para uma futura filosofia da fotografia. Rio de Janeiro: Relume Dumará, 2002.

MAFFESOLI, Michel. O imaginário é uma realidade. Revista FAMECOS. Porto Alegre, n. 15, 74-82, $2001 b$.

ROCHA. Ana Luiza. Antropologia das formas sensíveis: entre o visível e o invisível, a floração de símbolos. In: Horizontes Antropológicos, Antropologia Visual. Ano 1, vol. 2, 1995.

ROCHA, Ana Luiza Carvalho da. Tecnologias Audiovisuais na Construção de Narrativas Etnográficas, um percurso de investigação. In: Campos, 4:113-134, 2003.

SIMMEL, Georg. A Ponte e a Porta. In: Política e Trabalho João Pessoa-PB, 1996.

Recebido em: 19/03/2015

Aprovado em: 13/06/2015 